\title{
Poder, violência e biopolítica: Diálogos (in)devidos entre H. Arendt e M. Foucault
}

Power, violence and biopolitics: Dialogues (in)owed between $\mathrm{H}$. Arendt and M. Foucault

* Castor M. M. Bartolomé Ruiz

\begin{abstract}
Resumo: Este ensaio tem por objetivo apresentar uma crítica das teses naturalistas da violência. O marco da crítica diz respeito à naturalização da violência, que induz a assimilação do poder como uma forma de violência. Para tanto, retomamos as teses de Hannah Arendt e Michel Foucault sobre o poder e a violência. O objetivo não é elencar as diferenças entre estes autores sobre o tema, que ficam explícitas no desenvolvimento do ensaio, mas mostrar as suas concordâncias a respeito da crítica do poder como algo sinônimo de violência.
\end{abstract}

Palavras-chave: Biopolítica. Poder. Violência. H. Arendt. M. Foucault.

\begin{abstract}
This paper aims to present a critique of naturalistic theories of violence. The context of this critique concerns the naturalization of violence, which induces the assimilation power as a form of violence. Therefore, we resumed the theses of Hannah Arendt and Michel Foucault on power and violence. The goal is not to list the differences between these authors on the subject, which are explicit in the development of the test, but show their concordance regarding the critique of power as something synonymous with violence.

Keywords: Biopolitics. Power. Violence. H. Arendt. M. Foucault.
\end{abstract}

\section{Introdução}

T Tm conjunto de obras e autores contemporâneos vinculados de diversas formas às ciências biológicas tem defendido o caráter natural da violência. Na maioria das obras, identificam-se como semanticamente

* Doutor em Filosofia. Pesquisador do Programa de Pós-Graduação em Filosofia - Unisinos. Coordenador Cátedra Unesco-Unisinos de Direitos Humanos e Violência, Governo e Governança. Coordenador Grupo de Pesquisa CNPq "Ética, biopolítica e alteridade". <castor@unisinos.br>. 
similares a violência, a agressividade, o poder e o conflito. Estas categorias são retrabalhadas como sinônimas da violência natural e esta, por sua vez, é considerada inerente a todos os seres vivos ${ }^{1}$. As ramificações das teses naturalistas na filosofia política são amplamente conhecidas. As teses naturalistas - da biologia, etologia, zoologia, neurociência, etc. - são utilizadas, comumente, como suporte argumentativo científico de base empírica para construir uma certa ética e filosofia política naturalizadas. Especificamente, há uma conexão orgânica muito estreita entre algumas concepções biopolíticas e o pensamento naturalista ${ }^{2}$. Esses vínculos mostram-se especialmente densos na explicação da violência como um instinto ou pulsão natural de todo ser vivo, e, consequentemente, do ser humano. O conatus de Hobbes abriu uma espécie de caixa de Pandora da natureza humana. Ao longo do tempo saíram dela novas funções, genes, neurotransmissores, sinapses, hormônios..., como suportes aparentemente naturais de uma violência inexorável.

A biopolítica contemporânea remete sua legitimidade, de uma ou de outra forma, à suposta naturalização do comportamento humano. De forma muito especial, naturaliza-se a violência como um instinto inevitável, que, por sua vez, assimila-se ao poder. Poder e violência interagem, na lógica biopolítica, como sinônimos de um instinto natural inevitável que deve ser eticamente tolerado, educativamente integrado e politicamente administrado. Neste paradigma, o poder é violento e a violência realizase como poder. A assimilação destas duas categorias, poder e violência, às pulsões da natureza humana, torna o poder naturalmente violento e justifica a violência como uma forma legítima do poder.

2. A questão que propomos para debate, neste ensaio, tem uma longa tradição no pensamento filosófico que vai desde Demócrito e Epicuro aos modernos Hobbes e Spinoza, desembocando no atual debate sobre o tema. Para confrontar o problema do suposto naturalismo da violência e suas implicações ético-políticas sobre o poder, propomos fazer uma

1 LORENZ, Konrad. On Agression. New York: Haurcourt, 1982; WILSON, Edward Osborne. Sociobiology: The new Synthesis, Harvard University Press, 1975; DAWKINS, Richard. The selfish genes. New York: Oxford University Press, 1989; Id. A grande história da evolução. São Paulo: Companhia das Letras. 2009; WRANGHAM, Richard; PETERSON, David. O macho Demoníaco. As Origens da Agressividade Humana. Tradução de Vera Barros. Rio de Janeiro: Objetiva, 1998; DAMÁsIO, Antônio. O Erro de Descartes. Companhia das Letras. São Paulo. 1996; DE WAAL, Frans. Chimpanzee Politics. The John Hopkins University Press. 1982; Id. Eu, Primata. Tradução de Laura Teixeira Mota. São Paulo: Companhia das Letras, 2007; Id. Good Natures: The Origens of Right and wrong in humans and the other animals. Cambridge: Harvard University Press, 1998; Id. Our Inner Ape. New York: Penguin Group, 2005.

2 Uma excelente análise genealógica das conexões da biologia com a biopolítica e tanatopolítica cf. ESPOSITO, Roberto. Bios, biopolítica e filosofia. Turin: Einaudi, 2004. Recomendamos, sobre este ponto, a leitura do cap. I. 
análise crítica destas duas categorias, violência e poder, a partir das reflexões de Hannah Arendt e Michel Foucault.

O principal objetivo deste ensaio não é fazer um estudo comparativo entre as posições teóricas de Arendt e Foucault a respeito do poder e da violência, mas confrontar suas posições com as teses naturalistas que reduzem o poder à violência, transformando a violência numa forma inexorável de poder. As diferenças entre as concepções destes autores ficarão explícitas nas análises que propomos, porém, sublinharemos seus pontos de encontro na crítica da violência desde a perspectiva do poder. Os cruzamentos teóricos destes autores intensificam-se em sua crítica da violência, centrada, muito especialmente, na violência biopolítica. Embora Hannah Arendt nunca utilizou o conceito de biopolítica, suas análises destacam, com muita clareza, a matriz biológica do poder moderno e, com ele, a tentativa de legitimar a violência como parte constitutiva do poder social. Este será o primeiro ponto de nossa pesquisa. No segundo ponto, desenvolveremos um esboço genealógico do poder em relação à violência, na obra de Foucault. Concluiremos mostrando as relações (in)devidas entre estes dois autores a respeito da sua crítica ao poder como violência, ou à violência como mera naturalização do poder.

\section{Hannah Arendt, Sobre a violência}

Quer seja Clausewitz, chamando a guerra de 'continuação da política por outros meios', ou Engels, definindo a violência como acelerador do desenvolvimento econômico, a ênfase está na continuidade política ou econômica, na continuidade de um processo que fica determinado por aquilo que precedeu a ação violenta. ${ }^{3}$

3. As teses naturalistas da violência não são exclusivamente de matriz hobbesiana, elas foram abraçadas também por pensadores revolucionários, que defendiam o uso legítimo da violência revolucionária como única solução política à violência natural do poder instituído. Esta análise do naturalismo da violência revolucionária pode contribuir para enriquecer alguns aspectos importantes do debate filosófico sobre a violência, entre eles, a diferença entre poder e violência.

Inicialmente, retomamos a obra que Arendt escreveu com o título On Violence ${ }^{4}$. Nesta obra, Arendt propõe-se debater, entre outros aspectos,

3 ARENDT, Hannah. "Da violência". In: Crises da República, São Paulo: Perspectiva, 2010, p. 98.

4 ARENDT, Hannah. On violence. New York: Hancourt, 1970 (Tradução José Volkman. "Da violência". In: Crises da República, São Paulo: Perspectiva, 2010, p. 91-156). 
a questão da naturalização da violência instigada pelos debates que, na segunda metade do século XX, aconteceram sobre a legitimidade do uso da violência revolucionária. O objetivo da autora é questionar as teses de alguns autores como George Sorel, em sua obra Réflexions sur la violence (1908), e outros teóricos da revolução armada da década de 1960, como Pareto ${ }^{5}$ e Fanon ${ }^{6}$. Estes autores defendiam a legitimidade da violência revolucionária como único meio que restava aos oprimidos para opor-se à violência dos opressores. O ponto crítico deste debate encontrase na tese subjacente a estes autores de que a violência é natural e constitutiva do poder. Neste suposto, poder e violência identificam-se nos fins e só diferenciam-se nos meios. As relações de opressão são uma forma de violência estrutural que se legitimam como poder instituído. Se a violência é inerente ao poder, os oprimidos não têm outra alternativa que utilizara violência como meio justo para seus fins legítimos, ou seja, a emancipação da opressão. Neste suposto, a justificação da violência depende da legitimidade dos fins.

Arendt critica as teorias da violência que interpretam Marx de forma indevida para legitimar ações violentas como parte do projeto de sociedade socialista. Arendt critica, além de Fanon, as interpretações que Sartre faz de Marx e da violência como meio legítimo e coerente com a sua filosofia?.

A assimilação da violência ao poder coloca uma das armadilhas conceituais mais sinuosas da filosofia política, legitimando a violência como algo natural e o poder como naturalmente violento. Arendt percebe esta armadilha epistemológica e propõe-se a desarmar o nó conceitual que assimila semântica e politicamente ambas as categorias. A autora, no primeiro ensaio dessa obra, entende que a violência, a diferença do poder, necessita e utiliza ferramentas decorrentes das inovações tecnológicas. A proclividade da violência a utilizara tecnologia como ferramenta decorre do que Arendt denomina "verdadeira substância da ação violenta", que consistiria em seu direcionamento através da relação meios-fins. Sendo que os fins são indefinidos, e, portanto, estão sempre em perigo de ver-se superados pelos meios, a violência justificaria fazer, primeiramente, dos meios seus fins necessários para poder atingir qualquer outra finalidade posterior ${ }^{8}$. A finalidade humana é imprevisível, diferentemente das tecnologias cuja finalidade é inerente a elas como meios para conseguir

5 PARETO, Vilfredo. George Sorel. Paris: Ed. De l'Herme, 1986.

6 FANON, Franz. The Wretched of the Earth. Grove: Press Editions, 1961.

7 ARENDT, Hannah. "Da violência". In: 2010, p. 107.

8 Ibidem, p. 94. Crises da República, São Paulo: Perspectiva, 
determinados objetivos. Para Arendt, a principal característica da violência é o uso instrumental dos meios como fins para aumentar sua potência destrutiva. Essa lógica mostra que: "a violência alberga dentro de si um elemento adicional de arbitrariedade" 9 . Interessa compreender melhor em que consiste essa arbitrariedade da violência, porém este ponto, desenvolveremos mais adiante.

Desde a nossa perspectiva, a violência, a diferença da agressividade, é uma ação intencional que se dirige contra a negação da alteridade humana. Esta distinção torna-se nítida na diferenciação proposta entre violência e poder.

Arendt, no cap. 2 desta obra, centra a crítica da violência como algo diferente do poder. $\mathrm{Na}$ compreensão naturalista, é comum identificar a violência com o poder, nesse caso a violência seria a expressiva manifestação do poder. Nesta hipótese, se toda política é uma luta pelo poder (violento), a violência é o último gênero de poder ${ }^{10}$. O que está em questão neste debate é a noção de poder. Ao identificar o poder com a violência, entende-se que a essência do poder é a dominação do outro. Desde este ponto de vista, o poder exerce-se como dominação. Neste caso, afirma Arendt, se a essência do poder identifica-se com o domínio sobre os outros, certamente que não há maior realização do poder que a pura violência. Esta seria a verdadeira manifestação do poder ou o poder resolvido na sua máxima expressão ${ }^{11}$. Arendt retoma a crítica às teorias naturalistas que, na sequência de Hobbes, pretendem ter descoberto as bases naturais do poder afirmando que a dominação e a agressividade são instintos inatos na natureza humana. Menciona a John Stuart Mill, que afirma que a primeira lição das civilizações é a obediência, identificando dois desejos ou inclinações inatas da natureza humana: o desejo de exercer o poder sobre os demais e a aversão ao poder exercido sobre si mesmo. Arendt questiona o suposto naturalismo destes aspectos: o poder (como dominação) e a liberdade natural espontânea.

No lugar desta visão naturalista, Arendt propõe retomar a noção clássica das polis gregas ou das civitas romanas que criaram a prática da isonomia entre os cidadãos para pensar o exercício do poder como uma forma de governo entre iguais. As revoluções do século XVIII voltaram-se para esta concepção do poder como relação política de isonomia no governo. Daqui, deduz Arendt, que uma das diferenças mais significativas entre poder e violência reside no número. Enquanto

Ibidem, p. 95.

10 Ibidem, p. 116.

11 Ibidem, p. 117. 
o poder necessita de um número maior de pessoas para legitimar-se, a violência prescinde do número de pessoas porque sua essência reside nas técnicas. Reconhece que o domínio das maiorias também pode servir para sufocar os direitos das minorias e os dissensos, porém isso não significa que poder e violência sejam a mesma coisa ${ }^{12}$. O poder reconhece-se na expressão de todos contra um, a maioria opondo-se à tirania. A violência, por sua vez, reflete-sena relação de um contra todos. Esta nunca é viável sem a utilização de instrumentos e tecnologia, dessa lógica deriva a importância de que os meios tornem-se seus fins.

4. No terceiro ensaio da mencionada obra, Arendt questiona diretamente a naturalização da violência proveniente da biologia e da zoologia ${ }^{13}$. A autora reconhece que se perguntar pela natureza da violência envolve, por um lado, ingentes interesses sociais e econômicos que utilizam a violência de forma lucrativa. A indústria bélica tem um lugar de destaque neste empenho. Embora reconheça os interesses econômicos e políticos que subjazem a muitas formas de violência, a autora considera da maior relevância o debate com pensamentos naturalistas. Um primeiro questionamento diz respeito ao empenho por caracterizar o humano a partir do paradigma teromorfo. Por que tanto empenho em assimilar a conduta humana com a dos animais? Uma primeira resposta, mais simples, é porque, no marco dominante do empirismo epistemológico é mais fácil experimentar com animais que com humanos. Uma segunda resposta, mais consistente que a anterior, é porque os resultados empíricos com animais tendem a mostrar um naturalismo da violência que dificilmente poderá ser aferido de outras formas no ser humano. A identificação, de forma plana, dos instintos animais com o comportamento humano permite traçar uma línea contínua entre os estudos sobre a agressividade natural e a violência humana. Arendt retoma os estudos de Lorenz a fim de perfilar uma crítica a sua tese da violência natural humana. As reações violentas dos seres humanos, provocadas por emoções fortes como a raiva, costumam responder muito mais um sentimento de injustiça que à mera pulsão instintiva, afirma a autora. O sentido de injustiça provoca a raiva que, em muitos casos, leva a violência. $O$ peculiar da violência humana provocada por emoções fortes refere-se, muito mais, ao sentido de injustiça que à mera pulsão animal ${ }^{14}$. Em contrapartida, a ausência de emoções não promove a racionalidade.

\footnotetext{
12 Ibidem, p. 121.

13 Ibidem, p. 133.

14 Ibidem, p. 137.
} 
A frieza calculadora da tragédia alheia não é um sinal de racionalidade $^{15}$.

A autora identifica a existência de um elo naturalista que conecta a biologia com muitos discursos da filosofia política contemporânea, que desembocam na legitimação da violência como um dado natural dos seres vivos. Estes discursos também recebem a influência de filosofias vitalistas como as de Nietzsche e Bergson. $\mathrm{O}$ elo que une a biologia com a filosofia tende a naturalizar a violência como uma espécie de pulsão vital em que a violência forma parte da potência da vida. É possível reconhecer, neste registro, a influência da filosofia vitalista de Nietzsche e sua tese sobre a naturalização da violência. Por sua vez, Sorel inspira-se no conceito de elã vital de Bergson, a fim de considerar a violência um elemento produtivo da vida e da sociedade ${ }^{16}$. Para Sorel, a classe trabalhadora seria a nova pulsão de vida com potencial para desestruturar a mediocridade burguesa que impôs o capitalismo como sistema de injustiça social. A potência vital e histórica da classe trabalhadora manifesta-se na sua capacidade revolucionária de transformar o capitalismo. Para Sorel, o trabalhador é um criador de novas qualidades morais necessárias para o novo modelo produtivo. Neste marco de vitalismo histórico, a violência torna-se o meio natural através do qual a potência criativa da classe operária realizará a transformação do capitalismo ${ }^{17}$.

Arendt faz a crítica da violência natural a partir de uma série de distinções conceituais entre violência, poder, potência, autoridade e força. A autora aponta que a filosofia política precisa diferenciar estes conceitos porque se utilizam com frequência como sinônimos, quando, na verdade, refletem realidades diferentes. Arendt tem uma certa "prevenção filosófica" em definir as práticas humanas através de conceitos, porque seu método filosófico está mais centrado na análise das práticas. Contudo, ela considera pertinente alguns mínimos esclarecimentos conceituais sobre o uso dos termos, sem que isso implique uma predefinição classificatória das práticas.

15 Neste ponto, cabe fazer referência à análise que Adorno e Horkheimer fazem sobre a frieza moral da razão instrumental burguesa representada, paradigmaticamente, na figura sadomasoquista de Juliette. Juliette é friamente racional, profundamente racional, e graças a sua capacidade de analisar racionalmente suas vantagens pode utilizar frieza moral perante o sofrimento do outro, a fim de levar a cabo, exemplarmente, seu projeto de dominação total. ADORNO, Theodor W., HORKHEIMER, Marx, "Excursus II: Juliette ou Esclarecimento moral". Id. Dialética do esclarecimento. Rio de Janeiro: Zahar, 2006, p. 71-98.

16 ARENDT, Hannah. "Da violência". In: 2010, p. 145.

17 SOREL, George. Réflexions sur la violence. Paris: Rivière, 1936. 
Arendt define o poder como a capacidade humana, não simplesmente de agir, mas de agir coletivamente ${ }^{18}$. Por isso, o poder não reside nunca numa só pessoa, ele pertence ao grupo enquanto este coexiste como tal. Retomando a divisão de Cícero entre potestas e autoritas, o poder é a potestas do povo ou do grupo. Sem o coletivo social não há poder. Quando se diz de alguém que tem o que está no poder, é um uso metafórico do termo, porque, para Arendt, o poder só existe como potestas da coletividade.

A autora entende por potência algo que, a diferença do poder, pertence ao indivíduo singular. É a propriedade inerente a um objeto ou pessoa, faz parte de seu caráter ou modo de ser. Para Arendt, o conceito de força, utilizado habitualmente como sinônimo de violência, haveria que o restringir para o uso das "forças físicas da natureza". É o conceito que designa a liberação de energia nos movimentos físicos ou sociai $\mathrm{s}^{19}$. Por último, define a autoridade a partir do reconhecimento do valor moral de uma pessoa. A autoridade emana do caráter ético da pessoa. Alguém tem autoridade porque outros reconhecem nela virtudes e valores que inspiram essa autoridade. A autoridade não se impõe pela força, reconhece-se pelo consentimento ${ }^{20}$. Por fim, Arendt identifica a violência por seu caráter instrumental. A violência utiliza a potência dos instrumentos para multiplicar seus efeitos.

5. A crítica de Arendt ao naturalismo da violência deve contextualizar-se no marco da sua crítica do social. O social é um espaço criado pela Modernidade com objetivo de governar a vida humana, de modo similar a como era administrada a vida na oikos grega ${ }^{21}$. Para os gregos, a vida privada era uma privação em si, privava-se de possibilidade da vida pública. O indivíduo privado (idion) era a negação do público, sendo o espaço privado da oikos, o espaço que restava para os idiotas. Estes eram incapacitados políticos, não tinham poder para participar nas decisões do espaço público, por isso eram governados como seres biológicos no espaço da oikos. A ascensão moderna do social impregnou de sentido público a vida privada conferindo à política o sentido primário de administração das necessidades econômicas da vida biológica. O social é o espaço em que a política clássica é reduzida à economia, ou seja, ao gerenciamento

18 ARENDT, Hannah. "Da violência". In: 2010, p. 123.

19 Ibidem, p. 124.

20 Esta mesma visão de autoridade é desenvolvida pela autora em: Id. "¿Qué es autoridad?". In: . Entre el pasado y el futuro. Barcelona: Península, 2003, p. 145-226.

21 ARENDT, Hannah, The Human Condition. Chicago and London: The University of Chicago Press, 1998 (A condição humana. São Paulo: Forense Universitária, 2010). 
das necessidades vitais. Para Arendt, esta redução do político ao social trouxe consigo uma negação do político e uma ascensão do biológico como nova norma da política. A política moderna torna-se, cada vez mais, uma administração das necessidades biológicas, ou seja, uma biopolítica. A dimensão pública da política clássica é reduzida na modernidade à técnica econômica. A deliberação da linguagem na Ágora cede lugar às técnicas administrativas da vida humana ${ }^{22}$.

Para Arendt, no social, o ser humano é considerado como um ser biológico (zoe), uma espécie viva entre outras. O recorte biológico do humano define o status da nova política, que se converte em administração econômica das necessidades, ou seja, em biopolítica. As atividades privadas da mera subsistência adquirem na sociedade um caráter público e passam a formar parte das estratégias políticas de governo. A própria política restringe-se, cada vez mais, à resolução de necessidades biológicas. O social retira o caráter político do espaço público, esvaziando-o da possibilidade da autonomia e da deliberação coletiva, substituindo autonomia e deliberação por administração técnica das necessidades ${ }^{23}$. A política moderna sofreu uma inversão conceitual e epistemológica a respeito da política clássica. Esta autocompreendiase como um espaço diferenciado da mera vida natural (zoe) em que era possível deliberar pelo exercício público da autonomia e da linguagem a respeito da felicidade humana além das meras necessidades biológicas, que ficavam restritas à oikos. Neste espaço privado, o ser humano, ao igual que o resto dos seres vivos, deveria prover sua subsistência e resolver suas necessidades biológicas. $\mathrm{Na}$ oikos, reina o império da necessidade e caracteriza-se pela administração das necessidades. A polis era o espaço alternativo à pura necessidade biológica, sendo a política a ação que ia além da mera reprodução das necessidades. Este marco conceitual da política clássica foi subvertido pela sociedade moderna.

A tríplice distinção que Arendt propõe entre labuta (labor), trabalho (work) e ação (action) corresponde à diferenciação que o ser humano consegue fazer distinguindo-se, assim, do resto das espécies animais. A labuta (labor) é a atividade que o ser humano compartilha com o resto dos seres vivos, animal laborans, para subsistir satisfazendo suas

22 “A administração da sociedade - a ascensão da administração do lar, de suas atividades, seus problemas e dispositivos organizacionais - do sombrio interior do lar para a luz da esfera pública não apenas turvou a antiga fronteira entre o privado e o político, mas também alterou a significação dos dois termos e sua importância na vida do indivíduo e do cidadão, ao ponto de torná-los quase irreconhecíveis." ARENDT, Hannah. A condição humana. São Paulo: Forense Universitária, 2010, p. 46.

${ }^{23}$ Ibidem, p. 71. 
necessidades biológicas. A labuta é uma atividade de consumo direito que se consome ao agir ${ }^{24}$. O trabalho produz o conjunto de artifícios de durabilidade. $\mathrm{O}$ trabalho de nossas mãos, a diferença da labuta de nosso corpo, fabrica coisas duráveis, homo faber ${ }^{25}$. A ação é o que distingue de forma singular o ser humano do animal. Na ação criam-se, pela linguagem, formas novas de ser. A ação origina a política.

A Modernidade inverteu a valoração clássica do sentido da labuta e do trabalho a respeito da ação. Tornou o trabalho o valor central da sociedade, fazendo da manutenção da vida biológica o principal objetivo do social. A política, por sua vez, foi transformada numa técnica administradora das demandas sociais e suas necessidades biológicas. A sociedade tornou-se uma sociedade de trabalho e consumo. Trabalhar para consumir, consumir para trabalhar. $\mathrm{O}$ ciclo de trabalho e consumo resume o principal objetivo de política moderna. A economia invadiu o sentido da política reduzindo-a à mera gestão das necessidades de consumo e bem-estar.

6. Para Arendt, a distinção clássica entre a oikos e a polis era essencial para manter o caráter singular da política a respeito da oikonomia, mas também para neutralizar a violência ${ }^{26}$. A política é o espaço da deliberação consensual do debate não violento, a diferença da mera luta natural por suprir necessidades. Na oikos, imperava a violência como algo "normal" no mundo da vida. A oikonomia reproduzia a desigualdade "natural" entre homem e mulher, entre senhor e escravo, fazendo da violência um direito da condição natural dessa relação. A oikonomia é uma relação essencialmente violenta que reproduz uma desigualdade social como se fosse natural. A desigualdade natural da oikos era governada pela violência como um direito natural do senhor sobre os escravos, do homem sobre a mulher, do adulto sobre as crianças.

À diferença da oikonomia, a política era o espaço em que o ser humano conseguia diferenciar-se dos meros animais, afastando-se da pura violência. Na política, a violência oikonomica era substituída pela deliberação do logos. Na política, todos eram iguais, ninguém tinha direito natural a impor-se, com violência, sobre os outros. A construção política da isonomia neutralizou o sentido da violência oikonomica, propondo em seu lugar a necessidade da deliberação coletiva. O essencial da política era seu caráter não violento a respeito da oikos,

24 BAKAN, M. "Hannah Arendt's Concepts of Labor and Work". In: HILL. M. (Ed.). Hannah Arendt and the Recovery of the Public World. New York: St. Nartin's Press, 1979.

25 ARENDT, Hannah. A condição humana. São Paulo: Forense Universitária, 2010, p. 169.

26 OKSALA, Johanna. "Violence and the Biopolitics of Modernity". Foucault Studies, n. 10, Nov. 2010, p. 23-43. 
onde a violência podia exercer-se de forma normal. A política necessita da linguagem, da palavra, do debate para exercitar-se. A deliberação e o debate da palavra substitui a necessidade da violência. O que caracteriza a política é a persuasão não violenta. A política, para Arendt, é o espaço da ação em que o ser humano consegue romper o determinismo do biológico e o império da necessidade. É no político que a violência perde sentido; a violência, ao aparecer, descaracteriza o sentido do político. A política cria o espaço da deliberação não violenta. Quando a violência invade o espaço da deliberação, a política perde seu sentido para tornar-se outra coisa, talvez oikonomia.

Para Arendt, o horror da violência moderna não está alheio ao viés biopolítico que a sociedade operou na política. A hegemonia do social sobre o político, da necessidade sobre a autonomia, do biológico sobre a liberdade, produz vários tipos de violência específica, violência biopolítica. Para Arendt, uma das formas de violência biopolítica moderna é o terror. A Revolução Francesa foi um exemplo claro do modo como a violência do terror está vinculada à lógica biopolítica da pura necessidade. Na obra On Revolution ${ }^{27}$, a autora sustenta que o terror desencadeado na Revolução Francesa, na forma de matanças indiscriminadas de todo e qualquer suspeito, nada mais era que um desdobramento do império da necessidade invadindo a ação política. A Revolução Francesa foi comandada, inicialmente, pela necessidade da fome que impelia as massas famintas a cometer o horror como um fato normal da ação revolucionária. A pura necessidade básica da sobrevivência desencadeou uma violência instintiva, incontrolável, de massas famintas que perdiam a noção da política e entregavam-se à pura violência do horror como ato revolucionário ${ }^{28}$. Arendt entende que a pobreza extrema coloca as pessoas sob a ditadura da pura necessidade. "Os homens sob o ditame absoluto de seus corpos, isto é, sob a ditadura absoluta necessidade, como todos os homens sabem de sua experiência mais íntima e fora de todas as especulações"29. Sob o império da necessidade, as multidões praticam a violência como um ato de normalidade biológica. A violência biopolítica do terror foi uma decorrência do papel preponderante que a necessidade teve sobre a política na Revolução Francesa. A revolução foi impulsionada pelas necessidades biológicas de primeira ordem, deixando em segundo lugar os objetivos políticos de libertar-se da opressão feudal, de conseguir liberdades, de adquirir direitos ou instituir uma igualdade

\footnotetext{
27 ARENDT, Hannah. On Revolution. Harmondsworth: Penguin, 1990.

28 Ibidem, p. 27.

29 Ibidem, p. 60.
} 
política. Estes objetivos políticos ficaram totalmente ofuscados pela necessidade primária da fome e da miséria, que levou a revolução, inicialmente, a ter um caráter biopolítico de resolução de necessidades básicas. Isso fez fracassar a revolução.

A Revolução Francesa é um exemplo do modo como a violência social opera na política moderna, pervertendo-a e, em muitos casos, transformando a demanda do social no reino do terror. A emergência dos fascismos e do nazismo obedeceu a lógicas similares das aqui narradas. Ao tornar a necessidade um objeto político, a violência da necessidade tenta justificar-se como ferramenta própria da política. Para Arendt, a revolução é uma ação estritamente política. E a política só torna-se viável quando as necessidades básicas estão resolvidas. A revolução, como ruptura e surgimento do novo, não pode advir da pura violência da necessidade, mas da ação concertada dos cidadãos ${ }^{30}$. Quando a revolução identifica-se com a pura violência, perde seu caráter político para transformar-se em terror.

Para Arendt, a distinção entre o social e o político mantém uma íntima conexão com a distinção entre o poder e a violência. A identificação da necessidade biológica como objetivo da política leva a confundir a violência com o poder. Para Arendt, a política é o espaço da não violência, da deliberação, porque nele o ser humano liberou-se da pura necessidade biológica para poder criar novas formas de existência e ação.

\section{Michel Foucault, $O$ poder como positividade}

Uma segunda hipótese seria: o poder é guerra, é a guerra continuada por outros meios. $E$, neste momento, inverteríamos a proposição de Clausewitz e diríamos que a política é a guerra continuada por outros meios [...]

Creio que as duas noções de 'repressão' e 'guerra' (sobre o poder) devem ser consideravelmente modificadas, quando, talvez, no limite, abandonadas. ${ }^{31}$

7. Foucault foi um pensador que tematizou o poder de forma complexa e prolixa, sem, contudo, chegar a defini-lo. Suas pesquisas genealógicas mostraram diversos tipos de poder instituídos pela Modernidade, especialmente o poder disciplinar e o biopoder. Embora cada tipo de poder tenha uma especificidade própria nos dispositivos que cria e nas tecnologias através das quais se apresenta, todos eles, para

30 Ibidem, p. 181.

31 FOUCAULT, Michel. Em defesa da sociedade. São Paulo: Martin Fontes, 2000, p. 22-25. 
Foucault, diferenciam-se claramente da mera violência. No curso O poder psiquiátrico, de 1973, Foucault propõe uma crítica da noção de violência. O questionamento de Foucault à noção de violência diz respeito a sua vinculação com o poder, especificamente com uma espécie de poder físico que opera de forma irregular, passional ou desenfreada. O perigo que Foucault identifica nessa vinculação semântica da violência com o poder é que reduz o poder à violência, de tal modo que pareceria que o poder "bom", o que não utiliza a violência, simplesmente não é um poder no sentido estrito do termo, ou seja, ele não seria um poder físico porque não é violento ${ }^{32}$.

Foucault entende precisamente o contrário, que o poder não pode ser simplesmente identificado com a violência porque todo tipo de poder, mesmo não se utilizando da violência bruta, opera, em última instância, sobre o sujeito. Isso significa que o poder é sempre um efeito físico sobre o outro. Foucault enfatiza os efeitos de poder sobre o sujeito, que não são mera violência. Os efeitos de poder, afirma o autor, são efetivos, mas não necessariamente de uma violência brutal, física ou irracional. A distinção entre o poder e a pura violência, permite a Foucault perceber as conexões estreitas entre o poder sobre o corpo e a política: "Todo poder é físico, e há entre o corpo e o poder político uma ligação direta" 33 .

Um segundo ponto de crítica à noção de poder como violência diz respeito a uma interpretação reducionista da própria violência. A vinculação semântica da violência ao poder deixa transparecer a ideia de que a violência deva ser entendida, por um lado, como uma mera violação física e força irracional ou até desequilibrada do outro, e, de outro lado, pareceria que a violência física não faz parte da lógica racional de poder ${ }^{34}$. Neste caso, transparece que a violência brutal e física não formaria parte do jogo estratégico do poder, de suas táticas racionais de operar, de suas técnicas e modos de administrar a violência. Foucault afirma que, pelo contrário, a racionalidade instrumental também utiliza a violência como parte inerente de suas técnicas de poder, sem que isso signifique identificar-se com pura violência. $O$ poder, tal e como se exerce em muitas das instituições modernas, é meticuloso e calculado, e, no marco dessa racionalidade instrumental, a violência física também é pensada como um elemento tático útil e necessário. Inclusive, as formas estratégicas do poder

32 Idem. O poder psiquiátrico. São Paulo: Martin Fontes, 2006, p. 18.

33 Ibidem, p. 19.

34 "Depois, essa noção de violência não me parece muito satisfatória, porque ela deixa supor que o exercício físico de uma força desequilibrada não faz parte do exercício racional, calculado, administrado, do exercício do poder". FOUCAULT, Michel, op. cit., p. 19. 
que pretendem cooptar e administrar racionalmente a vida humana têm uma "ramificação capilar" onde o indivíduo é afetado na sua corporeidade. O indivíduo, reduzido a corpo pelas estratégias de poder, sofre um tipo de violência, não uma violência desenfreada e irracional, mas uma violência que opera numa espécie de microfísica do poder.

Foucault recusa-se a identificar o poder com a mera opressão ou pura repressão. Para Foucault, o poder é uma realidade produtiva. O poder opera como positividade que produz verdades, discursos e, através deles, os próprios sujeitos. Num sentido estrito, o poder acontece na relação e através dela manifesta-se como efeito da relaÇão ${ }^{35}$.

8. Foucault, no curso Em defesa da sociedade, de 1976, questiona-se qual o sentido metodológico do poder nas suas pesquisas. Inicialmente, rejeita definir o que seja o poder porque não é uma essência que se defina: "O que está em jogo é determinar quais são, em seus mecanismos, em seus efeitos, em suas relações, esses diferentes dispositivos de poder que se exercem, em níveis diferentes da sociedade, em campos e com extensões variadas" ${ }^{36}$. O poder deve ser analisado a partir de suas práticas, o que, inicialmente, para efeitos de análise genealógica, leva Foucault a considerar as práticas liberais e as marxistas do poder.

Foucault entende que, na teoria jurídica ou clássica - desenvolvida na Modernidade e que propiciou, entre outras, a noção de poder contratual -, o poder é considerado como um direito do qual alguém é possuidor e pelo qual também pode possuir algo. O poder seria uma espécie de bem específico que, em sua objetividade, poder-se-ia transferir para outros, ou alienar, ainda que parcialmente, na forma de um ato jurídico. Esta concepção do poder está na base da teoria contratual e da representação, segundo a qual o poder é algo que o indivíduo tem como posse ou até em propriedade e poderá ceder para constituir a teoria da soberania. A analogia que se estabelece neste modelo e nesta prática é que o poder está correlacionado com os bens e com a riqueza ${ }^{37}$.

Foucault também analisa a concepção marxista em que o poder é compreendido a partir de uma espécie de "funcionalidade econômica".

35 “O poder nunca é aquilo que alguém detém, tampouco é o que emana de alguém nem, aliás, a um grupo; só há poder porque há dispersão, intermediações, redes, apoios recíprocos, diferenças de potencial, defasagens, etc. É neste sistema de diferenças, que será preciso analisar, que o poder pode se pôr em funcionamento". FOUCAULT, Michel, op. cit., p. 7.

36 FOUCAULT, Michel. Em defesa da sociedade São Paulo: Martin Fontes, 2000, p. 19.

37 Ibidem, p. 20. 
O poder operaria no campo das relações de produção, reconduzindo a lógica da sociedade de classes, suas lutas e interesses. Para Marx, o poder político explica-se a partir do poder econômico. A essência do poder estaria na lógica econômica das relações de produção. $O$ questionamento de Foucault, por um lado, diz respeito ao reducionismo do poder ao modelo jurídico político de posse e contrato, e, por outro, ao modelo marxista das relações de produção. Foucault reconhece que o poder é indissociável da economia e do político, porém questiona que essa conexão seja da mera subordinação funcional, como se o poder fosse uma ferramenta a serviço de uma ou outra racionalidade. Tampouco pode assimilar-se o poder a uma espécie de isomorfia formal a respeito da política e da economia, como se o poder se identificasse com as formas de governo, as instituições econômicas, etc.

Estes questionamentos conduziram Foucault a ensejar uma nova compreensão do poder que, levando em conta a influência política e econômica, não reduzisse o poder a estas formas. Para Foucault, o poder não existe como uma essência que se analisa, nem como algo que se possui. A questão de Foucault é pensar o poder a partir dos seus efeitos nas relações sociais, repensando uma nova perspectiva que ajude a compreender melhor o modo como se estruturam e operam as sociedades. Inicialmente, Foucault analisa algumas questões sobre poder, que se aproximam mais da sua própria visão, embora as considere insuficientes. Um dos pressupostos é que o poder: "não se dá, nem se troca, nem se retoma, mas que ele se exerce e só existe em ato" 38 . Haveria uma outra percepção de que o poder deve ser considerado como relação de força. Porém, é preciso questionar, afirma Foucault, o quê seria esse exercício do poder e qual a sua mecânica, para melhor entendê-lo.

Com essas questões de fundo, Foucault identifica uma concepção teórica, com a qual não concorda, que identifica o poder como aquilo que essencialmente reprime. O poder seria aquela relação de força que reprime os diversos âmbitos da vida, como a natureza humana, os instintos ou a classe social. O discurso contemporâneo que replica esta compreensão do poder não está inovando, simplesmente está reconstituindo as teses de Hegel, posteriormente expostas por Freud e Reich ${ }^{39}$. Para Foucault, o poder não deveria ser identificado com o puro mecanismo da repressão. Esta identificação opera, também, um reducionismo.

38 Ibidem, p. 21.

39 Ibidem, p. 22. 
Haveria uma segunda perspectiva do poder que o considera como uma relação de força. Esta concepção, em lugar de analisar o poder em si mesmo como algo que se possui e se transfere a modo de propriedade que se aliena ou objeto que se contrata, ou de compreendêlo funcionalmente em relação às relações de produção, considera o poder em termos de combate, conflito, batalha e guerra. O poder seria a continuação de lógica da guerra por outros meios. Foucault percebe como esta visão aproxima-se das teses de Clausewitz, invertendo seu sentido, embora conservando sua hipótese. A política, entendida como relação de força e conflito, seria a continuação da guerra por outros meios. Esta percepção tem três consequências principais para Foucault. A sociedade estabelece-se a partir de uma relação de força que, de alguma forma e em algum momento, remete à guerra e pela guerra. Neste caso, o poder político neutraliza a guerra só em aparência. Seu objetivo, enquanto política, não seria anular a lógica da guerra, mas suspender seus efeitos modificando os métodos. A política limitar-se-ia a reinserir a lógica da força nas relações sociais. Isso implicaria uma espécie de guerra permanente e silenciosa, a política tornar-se-ia: "a sanção e recondução do desequilíbrio das forças manifestado na guerra" 40 . Foucault entende que a lógica desta concepção do poder leva a concluir que, o que se considera "paz civil", com todos os acordos e dissensos políticos a respeito do poder, com o poder e pelo poder, seria interpretado como uma continuação da guerra. Todos os acordos e pactos seriam deslocamentos fragmentários da própria guerra.

Foucault entende que pensar o poder como força leva a uma terceira conclusão, a de que a decisão final sobre o justo ou injusto, o bem e o mal, o certo e o errado, numa sociedade não seria dos juízes, mas das armas. A guerra seria o árbitro definitivo de todas as controvérsias e dissensões. Nesse caso, o exercício do poder como guerra só poderia ser suspenso no final da última batalha ${ }^{41}$. Foucault denomina a esta segunda hipótese do poder, "por comodidade", hipótese Nietzsche, enquanto à anterior, a do poder como repressão, denomina de hipótese de Reich $^{42}$. Contudo, essas duas hipóteses não são inconciliáveis, pelo contrário, repressão e guerra encontram-se muito conexas, assim como os conceitos de soberania e opressão também eram relacionados na teoria clássica.

\footnotetext{
40 Ibidem, p. 23.

41 Ibidem, p. 23.

42 Ibidem, p. 24.
} 
Teríamos, na perspectiva de Foucault, duas visões diferenciadas do poder, por um lado, a teoria clássica com seu binômio contrato-opressão, e, por outro, uma compreensão mais recente da guerra-repressão. A repressão, a diferença da opressão em relação ao contrato, não é um abuso do poder, mas um efeito do poder através do qual continua a dominação. A repressão propiciaria a continuidade da guerra no interior das relações de poder. O esquema contrato-opressão representa uma visão jurídica do poder que se estabelece entorno do legítimo ou do ilegítimo $O$ esquema guerra-repressão decorre da concepção do poder como relação de força e coloca em funcionamento a oposição lutasubmissão.

8. Foucault reconhece que suas pesquisas anteriores estiveram muito influenciadas por esta segunda visão do poder como lutarepressão. Porém, à medida que a sua genealogia das práticas, dos discursos e do sujeito foi-se desenvolvendo, também crescia nele uma certa insatisfação com alguns pontos desta concepção de poder. Questiona que as noções de "repressão" e de "guerra" sirvam para compreender o poder, entende que, como indica a epígrafe deste item, deverão ser modificadas e no limite abandonadas ${ }^{43}$. Foucault questiona que os mecanismos de poder sejam essencialmente de repressão e que a compreensão da política deva reduzir-se à mera guerra. As genealogias do poder que Foucault desenvolveu a respeito do direito penal, do poder psiquiátrico, da sexualidade e, posteriormente, sobre o cuidado de si e as técnicas de governo, mostraram que os mecanismos e os tipos como se implementam o exercício do poder são muito mais abrangentes e complexos que a mera repressão ou guerra.

No paradigma da guerra, mesmo na negação do conceito jurídicodiscursivo do poder, permanecia-se dentro da problemática jurídica da legitimação e da lei: num caso pelo contrato, no outro pela guerra. Ao afirmar que a concepção estratégica deve fornecer o "oposto" do modelo jurídico, aceita-se, inicialmente, o modelo jurídico, simplesmente negando-o: em vez de consenso e direito, coloca-se o constrangimento e a guerra. Foucault, em vez de tomar a macroperspectiva do Estado e a centralização dos detentores do poder, preferiu estudar a microfísica do poder e estratégias anônimas. O paradigma da guerra, como forma de legitimação do poder, proposto por Nietzsche, propunha como objetivo da análise política cortar a cabeça do rei. Porém, ao cortar a cabeça do rei, só virava a concepção da soberania de cabeça para baixo, substituindo a lei e o contrato pela guerra e a conquista, embora permanecendo dentro do paradigma da

43 Ibidem, p. 25. 
legitimação jurídica do poder. Dito de outro modo, o "corte" que se anunciava no paradigma da guerra a respeito do paradigma jurídico da soberania só poderia ser o primeiro passo.

Foucault propôs-se explorar um novo paradigma do poder introduzindo a temática do governo. O autor retomou a questão reposicionando a problemática das tecnologias do poder não mais no campo da soberania, senão das técnicas de governo. Foucault, distanciando-se da proposta de Nietzsche, mostra que as técnicas modernas de poder estão, acima de tudo, demarcadas pela noção de governo. No marco das pesquisas sobre as tecnologias de governo, Foucault entendeu que o próprio conceito de governabilidade não conotava suficientemente o sentido biopolítico que as técnicas governamentais adquiriram na Modernidade com a criação do Estado e do mercado. Ele decidiu criar o neologismo governamentalidade para pensar criticamente como operam as tecnologias de controle sobre as subjetividades no modelo capitalista de produção e no Estado moderno ${ }^{44}$.

Para Foucault, o poder não pode ser acumulado em uma espécie de centro, despojando de poder às periferias, nem pode ser localizado num topo a partir do qual se irradia para as bases. O poder é uma prática dimensionável pelos seus efeitos, através dos mecanismos que utiliza e nas relações que percorre. Ele não pode ser definido de forma substancial, nem explicado de forma exaustiva. O poder, por ser uma prática, é maleável, fugaz e histórico. Seu ser deve ser rastreado na genealogia das práticas ${ }^{45}$. O poder circula nas relações, o poder é inerente à relação. O poder atravessa todas as esferas sociais, impregnando toda ação da relação.

Poder não significa dominação ou opressão do outro, mas efeito sobre o outro. Toda relação tem um efeito, esse efeito opera como uma potência com poder de influenciar, mudar ou transformar. O poder é a potência da relação para construir positividades. Não há relação sem efeito de poder, são os efeitos de poder que qualificam o tipo da relação, assim como não existe poder fora da relação. Não existe um dualismo entre relação

44 "Por governamentalidade entendo o conjunto constituído pelas instituições, os procedimentos, análises e reflexões, os cálculos e as táticas que permitem exercer essa forma bem específica, embora muito complexa, de poder que tem por alvo principal a população, por principal forma de saber a economia política e por instrumento tecnológico essencial os dispositivos de segurança". FOUCAULT, Michel. 2008. Segurança, território e população. São Paulo: Martin Fontes. p. 141.

45 "O que é o poder? Seria justamente uma questão teórica que coroaria o conjunto, o que eu não quero - o que está em jogo é determinar quais são, em seus mecanismos, em seus efeitos em suas relações, esses diferentes dispositivos de poder que se exercem, em diversos níveis da sociedade, em campos e com extensões tão variadas". FOUCAULT, Michel. Em defesa da sociedade. São Paulo: Martin Fontes, 2000, p. 19. 
e poder, ambos estão imbricados e qualificam-se mutuamente. O efeito de poder que se provoca caracteriza o tipo de relação que se estabelece. Toda relação com o outro produz, como positividade, um efeito de poder sobre o outro e sobre o próprio sujeito que age. Identificar o poder com dominação ou violência é reduzir, de forma muito estreita, o poder. É certo que o poder poderá ser violento e dominador, mas a violência e a dominação não são nem a essência do poder, nem a sua qualidade maior, são efeitos possíveis, embora não determinados pela substância essencial do poder. Foucault caracteriza o poder disciplinar, por exemplo, como um poder que não se restringe a retirar violentamente ou apropriar-se pela força, algo característico do poder soberano, este muito mais identificado com a força, a repressão e a violência. O poder disciplinar almeja produzir, tornar produtivo o sujeito, multiplicar as potencialidades do indivíduo nas funções destacadas a ele. Enquanto o poder violento almeja constranger pela força, o poder disciplinar adestra o sujeito, treinando-o de forma racionalizada nas suas habilidades e competências, a fim de tornar-se um indivíduo produtivo e eficiente. O poder disciplinar, como toda forma de poder, fabrica um tipo de indivíduo. Neste caso, a disciplina é utilizada como técnica que objetiva os indivíduos como elementos naturais a serem formatados ${ }^{46}$. O poder opera produtivamente, para conseguir moldar o tipo de sujeito colaborativo demandado pelas sociedades modernas. A aparente "humildade" deste tipo de poder garante-lhe uma maior eficiência.

Se o indivíduo, na sua corporeidade física, é o objeto do poder disciplinar, a população, na sua realidade biológica, é o objeto do biopoder. O biopoder não opera pela pura violência nem se implementa pela mera força. O objetivo do biopoder é o governo da população a partir da sua natureza; não forçando com violência a natureza, mas a governando com inteligência. O biopoder evita os mecanismos violentos, próprios do poder soberano, em seu lugar coloca em funcionamento as técnicas de governo da vida ${ }^{47}$.

9. O poder disciplinar e o biopoder pretendem objetivar, de modos diferentes, a vida humana de forma instrumental. Nas suas técnicas,

46 FOUCAULT, Michel. Vigiar e punir. Petrópolis: Vozes, 1986, p. 153.

47 "A ideia de um governo dos homens que se pensaria antes de mais nada e fundamentalmente na natureza das coisas, e não mais na natureza dos homens, a ideia de uma administração das coisas que pensaria antes de mais nada na liberdade dos homens, no que eles querem fazer, no que têm interesse de fazer, no que eles contam fazer, tudo isso são elementos correlativos. Uma física do poder ou um poder que se pensa como ação física no elemento da natureza e um poder que se pensa como regulação que só pode se efetuar através de e apoiando-se na liberdade de cada um, creio que isso aí é uma coisa fundamental." FOUCAULT, Michel. Em defesa da sociedade. São Paulo: Martin Fontes, 2000, p. 64. 
afastam-se dos métodos da violência brutal e ameaçadora, própria do poder soberano. Contudo, não se pode negar que sob essa camada superficial de racionalidade instrumental opera um outro tipo de violência estrutural que instrumentaliza a vida humana como mero elemento natural. As técnicas "não violentas" destes tipos modernos de poder encobrem um outro tipo de violência, diferente do modelo da repressão e da guerra, caracterizado pelo uso instrumental da vida humana através da sua inserção produtiva, pela administração eficiente dos desejos e pela gestão utilitária das liberdades. A violência do velho poder soberano que deixa viver e faz morrer, agora é substituída por um paradoxo biopolítico que faz viver e deixa morrer. A violência amedrontadora do direito de morte, do poder soberano, é substituída pelo governo eficiente da vida. O paradoxo do poder moderno (poder disciplinar e biopoder) abandona aparentemente toda violência brutal, pondo em seu lugar mecanismos de valorização da vida humana como objeto de poder e governo.

Foucault entende que a entrada da vida nos cálculos do poder provocou que o biológico reflita-se diretamente no político, isso é um fato novo na história ${ }^{48}$. A biopolítica caracteriza-se pela entrada da vida, enquanto elemento biológico da natureza (zoe), como objeto dos cálculos explícitos do poder nas estratégias de cooptação e nas técnicas de governo. Foucault reconhece, aqui, a inversão do paradigma formulado por Aristóteles que entendia que o homem era um animal que, além de viver, era capaz de política, enquanto para a Modernidade o homem é simplesmente um animal cuja vida biológica há de ser o objeto principal da política ${ }^{49}$. A objetivação biopolítica da vida humana afasta-se da violência brutal do poder soberano, mas perpetra um outro tipo de violência estrutural mais sofisticada e também mais paradoxal. Porém, o biopoder não pode ser reduzido à mera violência, como mostraremos nas conclusões a seguir, o que, para Foucault, desvincula o poder da sua pretensa condição de naturalidade.

\section{Conclusões (in)devidas}

10.As análises de Hannah Arendt abrem pistas importantes para continuar o processo da crítica filosófica ao naturalismo da violência. Ainda que a autora não tenha formulado explicitamente o conceito

\footnotetext{
48 FOUCAULT, Michel. História da sexualidade I. A vontade de saber. Rio de Janeiro: Graal, 1999, p. 134.

49 Ibidem, p. 134.
} 
de biopolítica, suas análises percebem as implicações biopolíticas da violência naturalizada: "Nada, na minha opinião, poderia ser teoricamente mais perigoso que a tradição do pensamento orgânico em questões políticas" 50 . A violência, reduzida ao nível do instinto biológico, torna-se um meio útil para legitimar a barbárie ${ }^{51}$. Outrossim, Arendt, sem utilizar o conceito de biopolítica, desenha criticamente o marco biopolítico pelo qualse legitima a violência natural em sua relação com a biologia. Estes vínculos concretizam-se na tentativa moderna de governar a vida humana como recurso biológico. A biopolítica permanece, no pensamento de Arendt, como o contexto em que se desenvolvem as implicações da violência naturalizada. O vínculo orgânico, no sentido estrito do termo, entre biologia e política projeta esta, e o poder inerentea ela, no domínio da expansão violenta: " $D a$ mesma forma que no reino da vida orgânica tudo cresce e decai, se supõe que no reino dos assuntos humanos, o poder pode se sustentar a si mesmo só através da expansão; de outra forma, se reduz e morre"52. Este é um dos pontos nevrálgicos da biopolítica a ser desconstruído criticamente.

As diferenciações conceituais propostas por Arendt permitem concluir que o poder é inerente aos grupos sociais e a todas as formas de governo. Não é possível a existência de um grupo ou de um governo sem a relação do poder. O poder é da essência do governo, a violência não. O poder emana da potestas coletiva para decidir conjuntamente sobre os destinos do grupo. A violência não é essencial ao governo nem aos grupos sociais. Ela é, por essência, instrumental: instrumentaliza outros meios para legitimar seus fins. Seu caráter de meio exige que sempre tenha que procurar uma justificativa que legitime sua existência. A violência necessita legitimar-se permanentemente para poder existir, caso contrário, torna-se supérflua e há de desaparecer. Isso induz a violência a procurar formas de legitimar sua existência e continuidade. Arendt confirma que: "o que necessita justificar-se

50 ARENDT, Hannah. "Da violência". In: 2010, p. 101.

51 Neste ponto, apontamos uma discordância parcial com a opinião de Agamben de que: "as agudas indagações que Hannah Arendt dedicou na pós-guerra à estrutura dos Estados totalitários tem um limite, a falta de qualquer perspectiva biopolítica". Id. Homo Sacer. O poder soberano e a vida nua. Belo Horizonte: UFMG, 2002, p. 126. Se bem é certo que Arendt não vinculou diretamente suas análises biopolíticas da Condição Humana com suas pesquisas sobre o totalitarismo, no estudo da violência que apresentamos transparece a dimensão biopolítica como contexto e paradigma legitimador da violência natural, que conduz inexoravelmente à barbárie.

52 ARENDT, Hannah. "Da violência". In: 2010, p. 101. 
por algo, não pode ser a essência de nada"53. A violência, sendo um meio instrumental e nunca um fim, "pode estar justificada, mas nunca é legítima". Sua justificação perde sentido, torna-se injustificável em referência ao fim que pretende (que é, nesta visão, a negação política do poder). Ainda que, em alguns casos, ela possa ser justificada, nunca será a finalidade do poder nem o objetivo da política.

Diferentemente da violência, o poder não necessita justificar-se, ele é inerente à existência do povo e dos grupos sociais. Ele existe por e através das relações estabelecidas e definidas pelo grupo social. O poder constitui o modo de ser do grupo social. Por isso, o poder é um fim em si mesmo. Longe de ser um mero meio para um fim, ele é a finalidade do grupo social. O poder não necessita justificar-se porque pertence à essência das comunidades políticas. A comunidade política só pode existir através das relações de poder que pertencem ao coletivo na forma de potestas.

O que o poder necessita é legitimidade. Há uma diferença importante entre justificar-se e legitimar-se. O poder não necessita justificação porque é a finalidade da comunidade política, um fim necessário para que exista grupo ou comunidade política. Porém, ele necessita legitimar-se porque se sua justificação é concomitante à relação coletiva das pessoas, sua legitimidade deriva das decisões do coletivo. O questionamento sobre sua legitimidade resolve-se invocando o passado em que se decidiram as formas do poder, porém sua justificação remete a uma finalidade que se projeta no futuro, aquilo que a comunidade quer ser. A diferença entre justificação e legitimidade afeta de forma diferente à violência. Esta, diz Arendt, haverá circunstâncias em que se justifique (por exemplo, a defesa própria), mas ela nunca terá legitimidade. Inclusive, sua presumida justificação perde consistência na medida em que afasta para um futuro a finalidade que se propõe justificar ${ }^{54}$.

A relação entre violência e poder não é de identidade nem de assimilação semântica. Muito pelo contrário, os meios através dos quais o poder utiliza a violência afetam à legitimidade do poder. Sendo o poder uma finalidade necessária, a violência sempre será um meio prescindível. Se o poder requer a cooperação do maior número de pessoas para legitimar-se, a violência utiliza os instrumentos como ferramentas que aumentam sua potência. Afirma Arendt que esta distinção é importante porque aqueles que se enfrentam à violência com o simples poder, cedo haverão de descobrir que não se enfrentam com pessoas, mas com artefatos que aumentam a potência da destruição. A

53 Ibidem, p. 128.

54 Ibidem, p. 129. 
violência pode, simplesmente, destruir o poder ${ }^{55}$. Quando se substitui o poder pela violência, o preço a pagar é muito elevado, tanto pelas vítimas como pelos vencedores, cujo poder terá uma difícil legitimidade. A violência que excede toda justificativa do poder provoca a inversão total de fins e meios. Os meios de destruição tornam-se fins em si mesmos, cuja consequência será a destruição de todo poder. O exemplo mais concreto desta inversão é o uso do terror como meio político ${ }^{56}$.

Arendt conclui que o poder e a violência não são a mesma coisa, inclusive são politicamente opostos. Onde um domina, falta o outro. A violência apresenta-se e reforça onde o poder fraqueja, o impulso último da violência levará ao desaparecimento de todo poder. $\mathrm{Na}$ perspectiva apresentada por Arendt, uma questão grave é saber quando a violência é justificada, que, por sua vez, remete à questão, quando o poder pode fazer uso justificado da violência? Esta questão, assim colocada, tem uma difícil solução uma vez que, na maioria dos casos, os critérios que justificam a violência são validados pelo próprio poder.

10.Se a conclusão final sobre o biopoder e o poder disciplinar de Foucault, entre outros tipos de poder, fosse que eles também são intrinsecamente violentos, confirmaria, de outra forma, a tese naturalista da violência ou, ainda, as teorias do poder como repressão e força. Porém, a partir do pensamento de Foucault, é possível identificar dois paradoxos através dos quais o biopoder e o poder disciplinar legitimamse socialmente como biopolítica e tanatopolítica, mostrando que eles não são intrinsecamente violentos.

Em primeiro lugar, nem todos os efeitos do biopoder e da disciplina são estritamente negativos para os sujeitos. Há uma dose de organização disciplinar importante e necessária para que as decisões sejam implementadas, as instituições funcionem, os projetos executemse e as metas cumpram-se. Uma certa racionalização disciplinar de todos os âmbitos da vida humana e social traz importantes benefícios para as pessoas individuais e para as instituições. Da mesma forma, a estratégia biopolítica de cuidar e governar a vida humana como um bem natural valioso para o Estado e para o mercado tem efeitos positivos em muitos casos, pensemos nas estratégias de saúde coletiva, nas campanhas de vacinação, nos projetos de gestão da educação pública, dos alimentos, da água, dos espaços urbanos, etc. Uma gestão eficiente da vida humana também pode trazer muitos

55 Ibidem, p. 130.

56 Ibidem, p. 131. 
benefícios para a própria vida humana. A biopolítica legitima-se socialmente porque origina muitos benefícios individuais e coletivos. Este é o lado positivo, produtivo do poder. O poder, como Foucault insistiu em afirmar, não é intrinsecamente perverso. $O$ biopoder e o poder disciplinar operam com efeitos positivos sobre a vida humana, são positividades. Isso os legitima social e politicamente como tipos de poder necessários e não violentos para o funcionamento das sociedades modernas.

O que está em questão é o paradoxo através do qual o mesmo poder que cuida da vida humana como objeto útil, pode abandoná-la quando se tornar inútil. O mesmo poder que defende a vida pelo direito, normatiza-a comportamentalmente, estabelecendo os parâmetros normativos que definirão sua inclusão e exclusão social. A mesma técnica de controle que oferece informação e segurança pode ser a que vigia, espia e ameaça. Os mesmos dispositivos de segurança que garantem uma boa gestão das coisas (alimentos, urbanismo, saúde, etc.) podem especular sem limites na lógica do lucro indefinido. As mesmas disciplinas que organizam o trânsito, os espaços, o tempo, podem instrumentalizar a exploração máxima da produção, a indefinição de um tempo totalmente produtivo. O sujeito poder ser sufocado e explorado pelas disciplinas, assim como poder fazer da disciplina uma técnica que lhe libera tempo e energias.

O segundo paradoxo, derivado do anterior, é que o biopoder e o poder disciplinar, ao inserir a vida humana de forma estratégica nos cálculos do poder, investiram-na de um poder que antes nunca teve. A vida humana, tradicionalmente, era considerada uma dimensão particular dos indivíduos, cujo cuidado e responsabilidade cabia-lhes. Ela não tinha nenhum significado político. Por isso, as teorias clássicas do poder e da política utilizavam categorias como a justiça, a liberdade, a igualdade, até a felicidade, etc., para pensar as instituições e as formas de governo, porém a vida humana biológica era uma categoria que não tinha poder simbólico nem valor político. A biopolítica inverteu, também, esta relação. Ao inserir de forma estratégica a vida humana no poder, investiu-a de um poder que antes não tinha. Na Modernidade, a vida humana emergiu como valor simbólico com potencialidade política. A potencialidade política da vida tem um poder paradoxal. Ela pode ser instrumentalizada na forma de objetivação utilitária, o que configuraria um tipo de poder violento. Porém, a vida, uma vez investida de poder político, pode insurgir-se como alternativa de resistência aos dispositivos de controle. A mesma vida que é instrumentalizada pelo biopoder, insurge-se, também como biopoder, na forma de categoria política que reivindica direitos. Este é o campo (simbólico) em disputa pelo 
atual discurso dos direitos humanos. O discurso dos direitos humanos pode ser instrumentalizado para legitimar, por exemplo, as guerras contemporâneas, os direitos de patentes, etc. Mas, o próprio discurso pode insurgir-se em nome da vida humana como instância crítica que questiona os dispositivos de controle que sufocam ou ameaçam a vida.

O biopoder pode ser violento, mas também pode insurgir-se contra a violência. Foucault detecta este paradoxo ao mencionar que, desde o século XIX, as grandes lutas já não se realizam em função dos antigos direitos, nem dos velhos ideais. O que agora se desencadeou como luta social é uma luta pela vida, em que: "a vida como objeto político foi de algum modo tomada ao pé da letra e voltada contra o sistema que tentava controlá-la. Foi a vida, muito mais que o direito, que se tornou objeto das lutas políticas, ainda que estas últimas se formulem através de afirmações de direito" 57 . O paradoxo do poder, sua potência, é que ele pode operar violentamente na forma de controle e normatização da vida, mas também pode-se insurgir contra os dispositivos de controle reivindicando a vida humana, sua dignidade e alteridade, como critério ético- político. O poder mantém a sua potência na possibilidade de redirecionar o sentido das ações. O poder é potência de (re)fazer diferentemente qualquer tipo de ação. O paradoxo do biopoder reflete a potência do poder em construir práticas diferenciadas e mecanismos diversos.

A vida é o novo campo de tensão política. Ela tem a potência ética de desconstruir a legitimidade dos dispositivos violentos que se validam como úteis e necessários, mas também é instrumentalizada como meio para legitimar esses mesmos dispositivos. Toda tentativa de naturalizar a violência conduz, inexoravelmente, a uma instrumentalização violenta da vida.

11.Como indicamos no início, o objetivo principal deste ensaio não é fazer uma análise comparativa entre as posições filosóficas de Arendt e Foucault, mas confrontar suas teses com a "perene" tentativa de naturalizar o poder como violência e de justificar a violência como uma forma legítima e inevitável do poder. Para ambos os autores, o poder distingue-se qualitativamente da violência na medida em que ele é constitutivo da formação política não violenta ou da política como ação da não violência (Arendt); ou é compreendido como positividade produtiva inerente às relações sociais (Foucault).

Preservando as diferenças filosóficas e conceituais dos autores, que são muitas, o distanciamento entre poder e violência, defendido por estes filósofos, possibilita compreender o poder como uma dimensão constitutiva das relações humanas e sociais, que opera como uma

57 Ibidem, p. 136. 
espécie de "imperativo" constituinte do agir humano. Por sua vez, a violência aparece como uma ação contingente e possível. Nessa condição de contingência, a violência também está aberta à desconstrução. $O$ poder só existe como prática e qualquer práxis humana em relação ao outro está perpassada por uma relação de poder. Não existe relação sem poder, nem poder sem relação. O poder é potência no sentido de que toda prática de poder tem a potencialidade de ser de uma ou de outra forma, temos o poder de constituir as relações de formas diferentes. $O$ imperativo do poder (ou, o poder como imperativo das relações) não impõe o modo como o poder há de ser, embora toda ação implique num efeito de poder. O poder pode ser não violento, pode ser o poder do cuidado, da ação solidária com o outro, do apoio mútuo, o poder ético. O poder é constitutivo da ação, mas nós somos responsáveis pelo tipo de poder que conferimos a nossas ações.

O que caracteriza a violência, diferencia-a do poder, é seu caráter contingente de ação intencional que nega, de alguma forma, a alteridade do outro. A violência, como o poder, também existe em relação ao outro. Porém, diferentemente do poder, toda violência representa uma destruição, total ou parcial, da alteridade do outro. O outro, sua negação, é a finalidade que identifica a violência. Sem a negação intencional do outro não existe violência. A intencionalidade é constitutiva da contingência da ação. Sem ela, a ação torna-se espontânea, imprevista, involuntária. Sem a intencionalidade, a violência perde a dimensão estratégica da negação do outro, descaracterizando-se como ato violento. A intencionalidade desdobra-se em responsabilidade. Toda violência elabora-se como ação estratégica contingente que demanda responsabilidade. Os instintos involuntários ou impulsos inconscientes desafiam-nos, mas não nos responsabilizam. O poder que temos de direcionar intencionalmente esses instintos e impulsos torna-nos responsáveis pelo que podemos fazer. A violência opera na fissura da potência do poder que se abre, no ser humano, com respeito a sua natureza biológica (zoe). A violência urde-se na possibilidade de agir de um modo ou de outro com e sobre os instintos. O poder é potência de dobrar-nos e desdobrar-nos sobre os instintos da natureza e sobre as circunstâncias da história para, com eles, decidir direcionar nossa ação. A violência é uma das possibilidades contingentes dessa decisão.

Estas premissas permitem observar a violência como uma forma contingente de poder. Ela não é um instinto compulsivo nem uma dimensão constitutiva da ação humana, mas um tipo de direcionamento dado ao poder que temos. Nós somos responsáveis pelas formas do poder que criamos, somos responsáveis pela violência que instituímos. A responsabilidade, além de uma categoria ética, transparece como 
dimensão constitutiva do poder. O poder impõe-se como dimensão da ação, conferindo ao sujeito a potência de definir o tipo de poder e suas formas de ação. A responsabilidade é imanente à potência do poder. A violência é uma possibilidade, entre outras, sua contingência torna-nos responsáveis e, concomitantemente, permite-nos pensar na sua desconstrução. A desconstrução da violência é uma possibilidade inerente à sua contingência. Ela é uma das possibilidades do poder, poder violento, mas também é possível pensar em estratégias para neutralizar este tipo de poder e suas formas de violência.

Entendemos que tanto para Arendt como para Foucault, o que perfaz o poder é, principalmente, a relação com o outro. O que está em questão no poder é o tipo de relação, ou seja, o outro. Essa dimensão da alteridade não é explicitamente desenvolvida nos autores, mas se encontra permanentemente conjugada nas análises do poder. O outro aparece numa espécie de invisibilidade da relação. O poder é a potência do sujeito, mas ela existe como potência da relação. O poder circulante coloca em jogo as interações das relações, refaz o tipo de relação, institui o modo como os sujeitos reconhecem-se ou confrontam-se. O poder inerente a toda ação remete a uma alteridade com a que interage, sobre a que influencia, com a que atua, pela qual se afeta, etc. A alteridade é a sombra do poder, aquela que constitui a possibilidade (ética) de sua qualificação.

A modo de exemplo sobre a coimplicação do poder com a alteridade, o que está em questão no paradoxo do biopoder e do poder disciplinar é a objetivação da vida humana como mero meio para fins outros. A violência potencial do biopoder e do poder disciplinar está associada à negação da vida humana como alteridade e sua consequente redução a mero meio útil para fins instrumentais. O limiar crítico que define a violência do biopoder e do poder disciplinar, assim como de todo tipo de poder, é a alteridade da vida humana. O modo como a vida humana entra no jogo da lógica do poder é o critério que define a (não)violência desse poder.

$\mathrm{O}$ outro interpela a respeito da valoração axiológica do poder. $\mathrm{O}$ poder não é negado pela alteridade, mas interpelado na sua qualidade e sentido. Uma teoria crítica do poder, assim como a desconstrução da legitimidade da violência, faz-se em referência à alteridade do outro, que interpela e questiona a respeito da (im)pertinência e da (in)justificação do tipo de poder. O modo como o poder afeta a alteridade humana - e todo poder tem um efeito - (des)legitima sua existência. O poder é inerente às relações humanas, mas sua potência desentranha a responsabilidade como dimensão ética do poder. Não é possível a ação humana sem efeito de poder, mas não há poder sem responsabilidade. A responsabilidade é proporcional à potência do poder. Desta forma, a potência do poder desdobra-se, também, em potência ética da responsabilidade. 


\section{Referências}

ADORNO, Theodor W.; HORKHEIMER, Marx. "Excursus II: Juliette ou esclarecimento moral". In: . Dialética do esclarecimento. Rio de Janeiro: Zahar, 2006.

ARENDT, Hannah. On violence. New York: Hancourt, 1970.

. On revolution. Harmondsworth: Penguin, 1990.

. The human condition. Chicago; London: The University of Chicago Press, 1998. Homo Sacer. O poder soberano e a vida nua. Belo Horizonte: UFMG, 2002. "¿Qué es autoridad?". In: Entre el pasado y el futuro. Barcelona:

Península, 2003. A condição humana. São Paulo: Forense Universitária, 2010. . "Da violência". Trad. José Volkman. In: . Crises da República. São Paulo: Perspectiva, 2010.

BAKAN, M. "Hannah Arendt's concepts of labor and work". In: HILL. M. (Ed.). Hannah Arendt and the recovery of the public world. New York: St. Nartin's Press, 1979. DAMÁSIO, Antônio. O erro de Descartes. São Paulo: Companhia das Letras, 1996. DAWKINS, Richard. The selfish genes. New York: Oxford University Press, 1989. . A grande história da evolução. São Paulo: Companhia das Letras. 2009. DE WAAL, Frans. Chimpanzee politics. The John Hopkins University Press, 1982. . Eu, primata. Trad. Laura Teixeira Mota. São Paulo: Companhia das Letras, 2007. Good natures: The origens of right and wrong in humans and the other animals. Cambridge: Harvard University Press, 1998. . Our inner ape. New York: Penguin Group, 2005.

ESPOSITO, Roberto. Bios, biopolítica e filosofia. Turin: Einaudi, 2004. Cap. I. FANON, Franz. The wretched of the Earth. Grove: Press Editions, 1961. FOUCAULT, Michel. Vigiar e punir. Petrópolis: Vozes, 1986. . História da sexualidade I. A vontade de saber. Rio de Janeiro: Graal, 1999. Em defesa da sociedade. São Paulo: Martin Fontes, 2000. O poder psiquiátrico. São Paulo: Martin Fontes, 2006. . Segurança, território e população. São Paulo: Martin Fontes, 2008.

LORENZ, Konrad. On Agression. New York: Haurcourt, 1982.

OKSALA, Johanna. "Violence and the Biopolitics of Modernity". Foucault Studies, 10 (2010), p. 23-43.

PARETO, Vilfredo. George Sorel. Paris: De l'Herme, 1986.

SOREL, George. Réflexions sur la violence. Paris: Rivière, 1936.

WILSON, Edward Osborne. Sociobiology: The new Synthesis. Harvard University Press, 1975.

WRANGHAM, Richard; PETERSON, David. O macho Demoníaco. As origens da agressividade humana. Trad. Vera Barros. Rio de Janeiro: Objetiva, 1998.

\section{Endereço postal:}

Centro Ciências Humanas

Av. Unisinos, 950 - Cristo Rei

93-022-000 São Leopoldo, RS, Brasil

E-mail: castor@unisinos.br

Data de recebimento: 22/07/2013

Data de aceite: $23 / 03 / 2014$ 